in their true perspective, and to enable the general reader to form some appreciation of the interest and value of the collection.

The University of London has established a degree in the history of science, and it is possible that other universities will follow suit; if so, collections in which students can follow the development step by step will be necessary for any proper appreciation of the subject. As these old instruments - not so much the antiques which are probably safe, but the intermediate links are being broken up every day by those ignorant of their importance, no time should be lost by other universities, especially the sister University of Cambridge, in forming a similar collection.

\section{Introduction to Biology.}

(r) Allgemeine Biologie: eine Einführung in die Lehre vom Leben. Von Prof. Dr. Max Hartmann. Erster Teil: Zelle, Statik, Dynamik und Stoffwechsel. Pp. vi+262. (Jena: Gustav Fischer, I925.) I2 gold marks.

(2) Outlines of General Zoology. By Prof. H. H. Newman. Pp. xvi+48o. (New York: The Macmillan Co., I924.) I6s. net.

(3) A Text-Book of Biology: for Students in General, Medical and Technical Courses. By Prof. W. M. Smallwood. Fifth edition, thoroughly revised. Pp. 393. (London: Baillière, Tindall and Cox, 1925.) r6s. net.

NoT T the least evident of the signs that biology is finding its place in a general education is the crop of books intended to introduce the student to it which is now appearing. Three such are before us.

(I) Prof. Max Hartmann publishes the first of two parts of a work founded on his lectures on general biology in the University of Berlin. This is in title and manner an introduction, it is true, but it is an introduction on an ample scale, and suited only to serious students. It is broadly and philosophically conceived, and worked out very systematically in the German way. Prof. Hartmann begins at the beginning. In an opening section he considers the philosophical prolegomena of the subject-the position of biology in the system of the natural sciences, the methodology of the biological sciences, and the scope of general biology.

In treating of methodology, Prof. Hartmann gives an interesting and very judicious exposition of the respective functions of generalising and exact induction, and of the part played by hypothesis and experiment in the development of the science. As might have been expected, he views general biology as primarily the study of cell life, and begins his exposition of its

No. 2918 , vOL. I 16 ] principles with a survey of our knowledge of the cell. He draws the very necessary distinction between cell and energid, but unfortunately adheres to a use of the former term which compels him to apply it to the whole body of various organisms, from bacteria to Caulerpa, which are much better described as non-cellular. It is a pity thus to reduce to absurdity a conception which, rightly used, is of much value. Upon the question of "generative chromidia," which is briefly discussed in this section, the recent observations of Sister Monica Taylor on the life-history of Amœba throw some further light. A survey of the various skeletal and formative structures of cells follows, and then a section upon various types of motion. Here some allusion to recent English and American work on amœboid movement might perhaps have been made. Muscular contractility and the organs which subserve it are discussed in an excellent summary.

Part I. of the work ends with an admirable survey of the interchange of matter and energy between the organism and its surroundings, illustrated by an elaborate tabular statement. The style throughout is clear, and the illustrations plentiful and well printed. We are promised Part II., which will complete the book, in the course of next year.

(2) and (3) The other two books are ordinary enough examples of a common type-the introductory textbook for elementary students. Prof. Smallwood writes for students of biology, Prof. Newman for those who are studying zoology. Each states briefly a number of elementary facts and theories. Each at least avoids giving the impression that biology consists in a knowledge of the comparative anatomy of a series of organisms and some speculations as to the course of their evolution, but neither, we think, has avoided the opposite danger of superficiality. Prof. Newman's is the better book.

\section{Our Bookshelf.}

The Foundations of Colloid Chemistry: a Selection of Early Papers bearing on the Subject. Edited, on behalf of the Colloids Committee of the British Association, by Emil Hatschek. Pp. I73. (London : Ernest Benn, Ltd., 1925.) I8s. net.

Mr. Emil Hatschek has rendered a real service to all students of colloid chemistry by collecting early fundamental papers on the subject, six by foreign investigators being translated into English. The book makes no pretence to develop a historical account of the growth of colloid chemistry, but rather indicates certain outstanding conclusions which subsequent research has substantiated.

The first paper is by Ascherson (I840), who dealt with protein absorption at the interface: oil-aqueous solution. His results have been almost entirely overlooked by the many investigators who have since 